\title{
SISTEM PAKAR DIAGNOSA PENYAKIT MATA MENGGUNAKAN METODE FORWARD CHAINING (Studi kasus RUMAH SAKIT UMUM DAERAH LAWANG)
}

\author{
Taufik Rachman ${ }^{1}$, Ratri Surya Pratiwi ${ }^{2}$ \\ 1,2,3 Program Studi Teknik Informatika, STT Stikma Internasional Malang \\ ktopik@gmail.com
}

\begin{abstract}
ABSTRAK
Rumah sakit merupakan fasilitas kesehatan yang sangat penting dalam kehidupan sehari-hari. Salah satu pelayanan kesehatan yang diberikan di rumah sakit adalah layanan konsultasi mata. Konsultasi mata dilakukan oleh dokter spesialis penyakit mata di rumah sakit. Jumlah dokter mata yang ada di RSUD Lawang hanya 1 orang dan jam pelayanan poli juga terbatas, sehingga ada beberapa pasien yang tidak dapat dilayani langsung karena keterbatasan tersebut. Salah satu alasan masyarakat enggan untuk memeriksakan mata ke fasilitas kesehatan karena waktu tunggu antrian yang cukup lama. Padahal banyak sekali masyarakat yang mengalami gangguan penglihatan. Dengan dibangunnya sistem pakar penyakit mata ini diharapkan mampu mempermudah masyarakat untuk memperoleh informasi penyakit mata berdasarkan gejala yang dirasakan, dan membantu masyarakat yang ingin melakukan konsultasi dengan dokter spesialis mata. Sistem ini juga membantu mayarakat yang ingin berkonsultasi langsung dengan dokter spesialis mata di rumah sakit dengan mendapatkan nomor antrian poli mata, sehingga pasien tidak perlu mengambil antrian secara manual di pendaftaran dan mengurangi waktu tunggu.
\end{abstract}

Keyword : Penyakit Mata, Sistem Pakar, Forward Chaining

\section{PENDAHULUAN}

Rumah sakit memiliki peran yang sangat besar dalam pelayana kesehatan bagi masyarakat, salah satu layanan diberikan oleh RSUD Lawang adalah pemeriksaan mata. Untuk mendapatkan pemeriksaan mata tersebut pasien harus berkonsultasi dengan dokter spesialis mata, namun dalam proses konsultasi terdapat kendala yang sering dikeluhkan oleh pasien yaitu kurang efisien karena lamanya waktu tunggu konsultasi. Hal itu perlu inovasi untuk membantu efisiensi proses konsultasi dengan sebuah aplikasi.

Keputusan No.129/Menkes/SK/IV/2008 yang dikeluarkan oleh menteri kesehatan [5] bertujuan untuk peningkatan pelayanan terhadap pasien, diamana salah satu indekatornya adalah waktu tunggu pelayanan rawat jalan tidak boleh lebih dari 60 menit, dimulai dari mendaftar sampai dilayani dokter spesialis, berdasarkan pengamatan yang dilakukan, pelayanan terkait aturan tersebut masih belum berjalan dengan baik atau kurang maksimal.

Sehingga masih banyak pasien yang harus menunggu sangat lama untuk mendapatkan layanan rawat jalan dimulai dari pendaftaran sampai dengan dipanggil atau masuk ruang periksa dokter, hal ini akan mengurangi kepuasan pelanggan terhadap layanan yang diberikan oleh rumah sakit.

Pada penelitian ini akah dibuat sebuah aplikasi sistem pakar untuk melakukan diagnosa pada penyakit mata dengan teknik penalaran maju (forward chaining), yang mencakup informasi penyakit berdasarkan tanda dan gejala dan mengurangi waktu tunggu pasien di pendaftaran maupun waktu tunggu di poli spesialis. Aplikasi ini akan digunakan oleh pasien yang akan berkonsultasi dengan dokter spesialis mata di RSUD Lawang. Pasien akan mendapatkan nomor antrian dan perkiraan waktu kedatangan sehingga pasien tidak menunggu terlalu lama dalam proses konsultasi.

\section{TINJAUAN PUSTAKA}

2.1. Sistem Pakar

Menurut Sutojo Sistem pakar atau sering juga disebut expert system merupakan sebuah sistem yang dibuat untuk melakukan keahlian yang dimiliki oleh seorang pakar dalam memecahkan atau menjawab pertanyaan dari suatu permasalahan. Pada sistem ini proses dilakukan dilakukan dengan melakukan dialog antara seorang yang bukan pakar dengan sistem pakar, sistem ini akan membantu dalam mengambil keputusan dan menyelesaikan permasalah tanpa harus bertemu dengan seorang pakar [10]

Turban mengemukakan bahwa Sistem Pakar adalah sebuah sistem yang mengadopsi cara berpikir seorang pakar ke komputer, dimana sistem ini dirancang dengan suatu model dengan tujuan menyelesaikan suatu permalahan seperti layaknya seorang pakar. [11] Dalam pembuatan sistem pakai ini, dilakukan kombinasi dari kaidah-kaidah penarikan kesimpulan atau inferencerules berdasarkan pada pengetahuan yang dimiliki oleh satu atau lebih pakar dalam suatu bidang tertentu, dan dari kombinasi pengetahuan tersebut dipasang pada komputer dalam sebuah sistem, yang selanjutnya sistem ini digunakan untuk membantu seseorang pengguna dalam proses pengambilan keputusan dalam menyelesaikan suatu permasalan tertentu.

Kusumadwi [6] menyatakan bahwa terdapat 2 tipe pengetahuan yang dapat disimpan dalam sebuah komputer, dimana pengetahuan ini disebut dengan basis pengetahuan, tipe pengetahuan tersebut adalah fakta dan prosedur. Yang harus dimiliki oleh sistem 
pakar salah satunya adalah kemampuan untuk menalar, saat keahlian-kealhian tersebut tersimpan dalam sebuah basis data pengetahuan dan disediakan juga program yang digunakan untuk mengakses basis data, [7,8] maka komputer dapat digunakan atau diprogram dengan tujuan membuat inferensi. Proses inferensi ini dapat disimpan di komputer dalam bentuk motor inferensi atau inference engine. Sistem pakar komersial sering kita jumpai dalam bentuk rule-based system, dimana pengetahuan disimpan dalam bentuk aturan-aturan, dimana aturan tersebut akan kita jumpai dalam bentuk IF-THEN. Selain itu fungsi lain sistem pakar adalah sistem ini dapat memberikan rekomendasi, hal ini yang membedakannya dengan sistem konvensional.

\subsection{Metode Forward Chaining}

Dalam penelitian ini digunakan metode forward chaining, dimana dalam metode ini dilakukan pelacaran kedepan dari suatu permasalahan, berawal dari fakta-fakta yang ada dan akan berakhir pada kesimpulan, metode forward chaining merupakan kebalikan dari motode backward chaining. Dalam metode forward chaining berawal dari fakta-fakta yang didapatkan pada awal proses atau bisa juga ditetapkan dalam suatu sistem pakar. [1,2] Dengan menggunakan premis yang ditentukan oleh user, dimana premisi-premis ini nantinya akan disesuaikan dengan fakta-fakta serta menggunakan aturan-aturan tertentu. Hasil yang akan diperoleh dari proses ini adalah sebuah fakta baru yang akan digunakan untuk proses lebih lanjut sampai mendapatakan sebuah kesimpulan akhir setelah tidak ada lagi aturan yang premisnya sesuai dengan fakta.

\section{METODE PENELITIAN}

\subsection{Analisis Sistem Sekarang}

Sistem yang saat ini dijalankan atau digunakan adalah sebagai berikut:

a. Pasien datang kemudian menuju ke bagian pendaftaran.

b. Kemudian pasien akan mendapatkan nomor antrian untuk mendaftar.

c. Pasien menunggu dipanggil berdasarkan nomor antrian pendaftaran

d. Untuk pasien baru maka harus menunjukkan KTP atau KK untuk mendapatkan kartu berobat.

e. Pasien lama di minta untuk menyerahkan kartu berobat yang sudah dimiliki.

f. Pendaftaran mencatat identitas pasien berdasarkan kartu berobat.

g. Pendaftaran akan mencari sokumen rekam medis pasien sesuai kartu berobat.

h. Pendaftaran memasukkan data pasien ke sistem informasi rumah sakit sesuai poli tujuan.

i. Pasien mendapat nomor antrian periksa di poli tujuan. j. Pasien diminta untuk menunggu panggilan didaerah ruang praktek dokter.

k. Setelah dipanggil pasien diminta masuk ke ruang praktek untuk diperiksa dan berkonsultasi.

1. Dokter akan menulis dokumen rekam medis pasien.

m. Dokter memberikan resep obat kepada pasien untuk dibawa ke kasir.

n. Pasien melakukan pembayaran ke kasir

o. Pasien menyerahkan resep obat ke apotek dan mendapatkan nomor antrian pengambilan obat.

p. Pasien menunggu sesuai nomor antrian pengambilan obat

q. Pasien mendapatkan obat sesuai resep dokter

\subsection{Sistem yang Akan Dibangun}

Berikut ini adalah rancangan dari sistem yang akan dibuat:

a. Pasien membuka halamn web sistem pakar dan memilih menu konsultasi.

b. Pasien mengisi data-data yang diperlukan dan melakukan pendaftaran secara online

c. Pasien menjawab beberapa pertanyaan yang disediakan dalam sistem pakar dengan jawaban ya atau tidak.

d. Pasien akan mendapatkan informasi mengenai setelah mengisi pertanyaan-pertanyaan seputar gejala penyakit, hasil yang ditampilkan dalam bentuk tanda, gejala, penyebab penyakit, dan solusi dari yang disarankan.

e. Jika pasien ingin melakukan pemeriksaan lebih lanjut dan bertemu langsung dengan dokter, pasien dapat memilih menu ambil antrian.

f. Pasien akan mendapatkan nomor antrian di poli mata pada hari tersebut.

g. Pasien dapat logout jika sudah selesai konsultasi.

\subsection{Analisa Peran Sistem}

Diharapkan sistem dapat membantu user dengan hasil sebagai berikut:

a. Sistem diharapkan akan memberikan kemudahan yang efektif bagi petugas rumah sakit, dalam melakukan konsultasi terhadap pasien di Rumah Sakit Umum Lawang.

b. Terdapat laporan jumlah pasien setiap harinya sehingga akan memudahkan petugas rumah sakit.

c. Terdapat informasi yang secara otomatis muncul di layar atau halaman web saat pasien melakukan konsultasi, untuk menampilkan layanan ini mengikuti hak akses

d. Terdapat laporan penyakit mata apa yang sering diderita pasien.

e. Sistem pakar ini bertujuan untuk memberikan informasi tentang penyakit dan obat yang cocok untuk pasien secara cepat, efektif walaupun dilakukan konsultasi secara online. 


\subsection{Analisa Peran Pengguna}

Dalam desain sistem pakar ini, peneliti merancarn sistem ini memiliki 3 jenis userdalam penggunaan sistem, yaitu :

a. Pasien

Pasien memilikih hak untuk menggunakan Sistem Pakar ketika ingin melakukan konsultasi penyakit mata, dengan cara mengisi data-data tentang pasien dan menjawab beberapa pertanyaan berupa seputar gejala apa saja yang dialami oleh pasien.

b. Admin

Admin memiliki hak untuk menggunakan Sistem Pakar dalam memasukan data-data penyakit, data-data gejala, data-data obat dan solusi yang disampaikan ke pasien dalam bentuk jawaban hasil konsultasi pasien, data resep dan serta aturan dalam mengkonsumsi obat

c. Dokter

Dokte memiliki hak untuk menggunakan Sistem Pakar untuk melihat hasil konsultasi pasien dan melihat antrian pasien

\subsection{Diagram Konteks}

Berikut ini adalah diagram konteks dari sistem pakar yang dibuat, dimana terlihat hubungan antar entity Pasien, Dokter dan Admin.

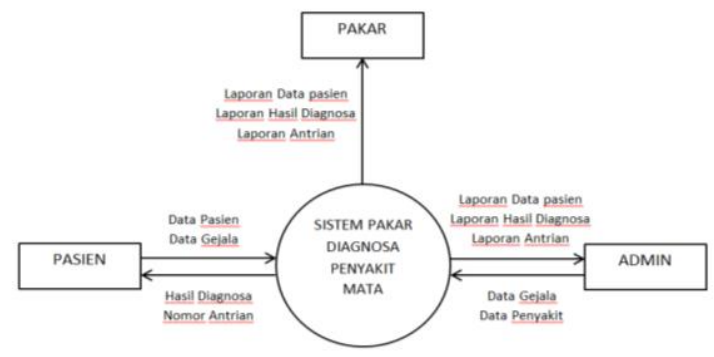

Gambar 1. Diagram Konteks

\subsection{DFD Level 1 ADMIN}

Gambar 2 merupakan gambar dari DFD level 1 dari Admin dimana terdapat proses login, setting data gejala, penyakit serta detail penyakit dan data antrian

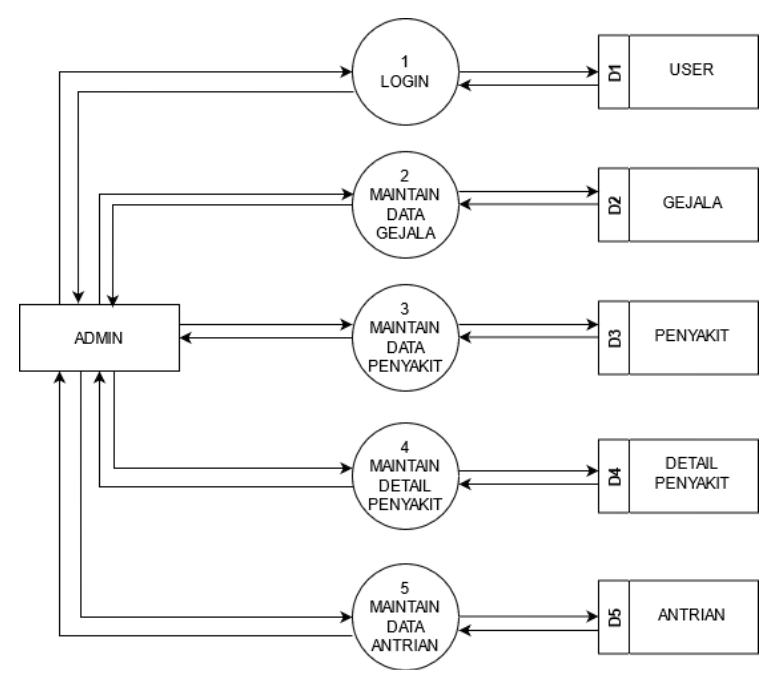

Gambar 2. DFD Level 1 Admin

\subsection{DFD Level 1 PASIEN}

Berikut ini adalah DFD level 1 dari pasien dimana terdapat proses register, login, input gejala dan daftar cek

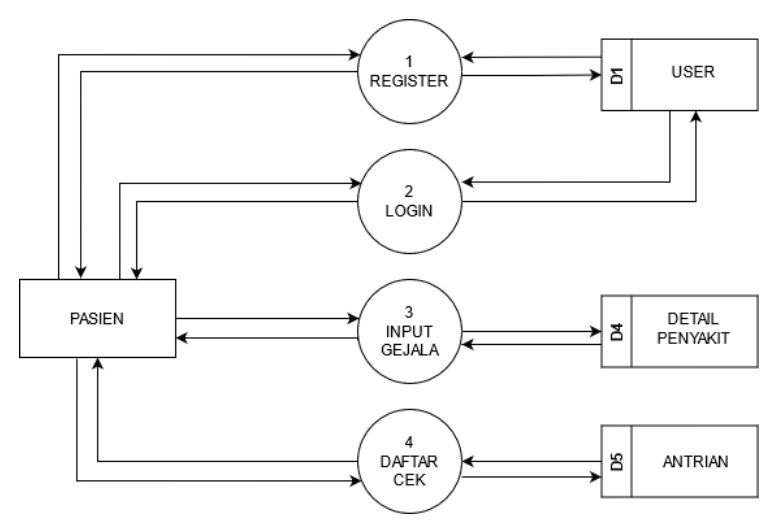

Gambar 3. DFD Level 1 Pasien

\subsection{ERD}

Pada gambar 4 dapat dilihat ERD dari sistem yang dibuat, terdapat Gejala, Detail Penyakit, Penyakit, User dan Antrian

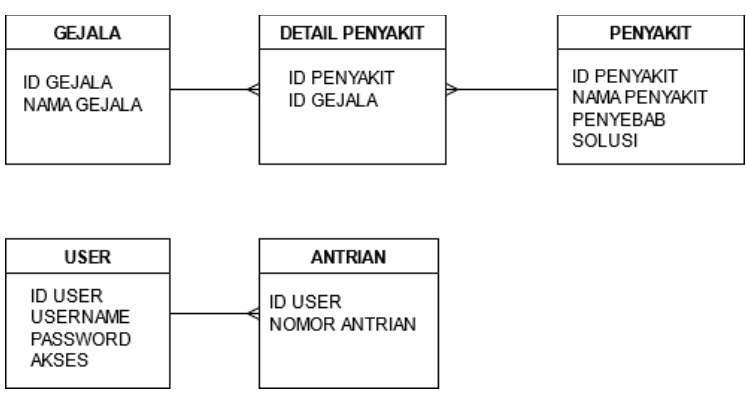

Gambar 4. ERD 


\subsection{FLOWCHART FORWARD CHAINING}

Dari flowchart dapat dilihat proses dari forward Chaining, mula-mula input gejala, sehingga diperoleh data penyakit, jika ada penyakit yang lain akan kembali ke input gejala, jika tidak ada penyakit lain akan muncul hasil analisa, kemudian pasien mengambil nomor antrian

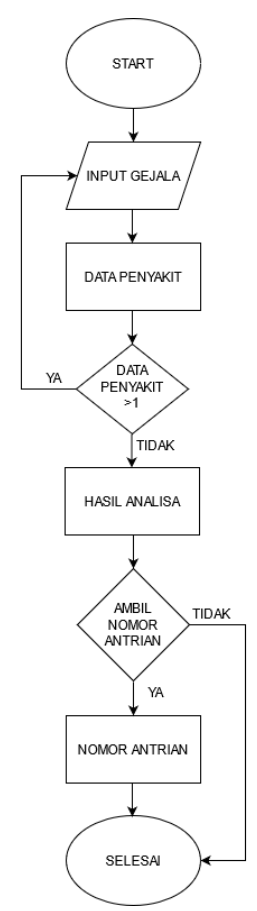

Gambar 5. Flowchart Forward Chaining

Dari flowchart dapat dilihat proses dari forward Chaining, mula-mula input gejala, sehingga diperoleh data penyakit, jika ada penyakit yang lain akan kembali ke input gejala, jika tidak ada penyakit lain akan muncul hasil analisa, kemudian pasien mengambil nomor antrian

\subsection{FLOWCHART ANTRIAN}

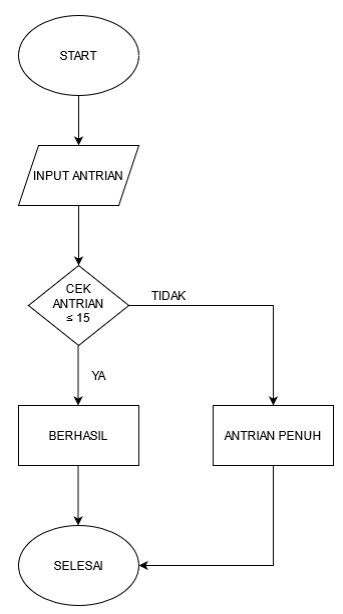

Gambar 6. Flowchart Antrian
Pada gambar 6 dapat dilihat proses dari antrian, dimulai dari menginputkan nomor antrian, kemudian terdapat proses pengecekan jumlah antrian, jika jumlah antrian melebihi batas, maka akan diinformasikan bahwa antrian sudah penu.

\section{HASIL DAN PEMBAHASAN}

4.1. Halaman Dashboard Admin

Pada halaman ini ditampilkan 5 menu yang digunakan oleh admin.

1. Dashmboard: Menu yang menampilkan halaman awal saat berhasil melakuakan login.

2. Data Penyakit: Menu yang digunakan admin untuk melihat daftar penyakit, hapus, tambah dan edit data penyakit.

3. Data Gejala: Menu yang digunakan admin untuk melihat daftar gejala, hapus, tambah dan edit data gejala.

4. Antrian: Menu yang digunakan admin untuk melihat daftar antrian.

5. Logout: Menu yang digunakan admin untuk keluar dari sistem.

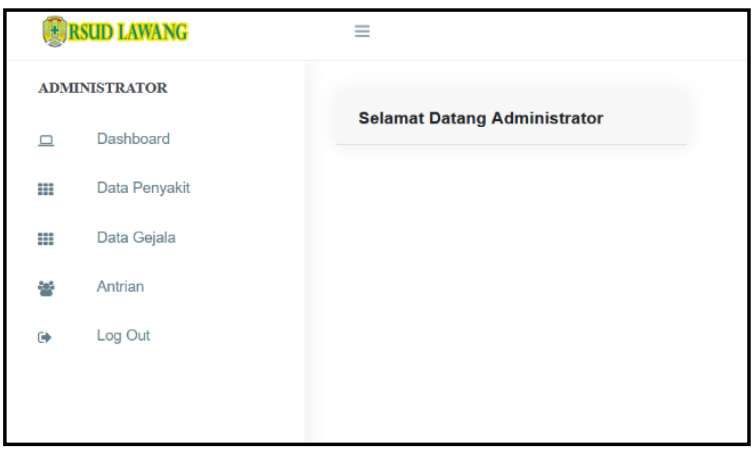

Gambar 7. Halaman Dashboard Admin

\subsection{Halaman Data Penyakit}

Pada halaman ini menampilkan data penyakit yang ada pada database, terdapat tombol tambah penyakit, edit penyakit, hapus penyakit dan daftar gejala yang berhubungan dengan penyakit tersebut.

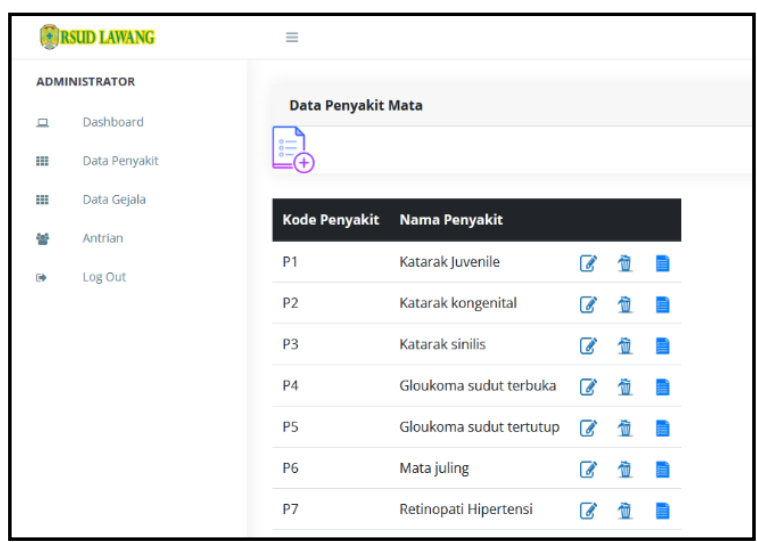

Gambar 8. Halaman Data Penyakit Admin 


\subsection{Halaman Daftar Gejala yang Berhubungan} Dengan Penyakit

Pada halaman ini admin dapat melihat daftar gejala yang berhubungan dengan penyakit tersebut.

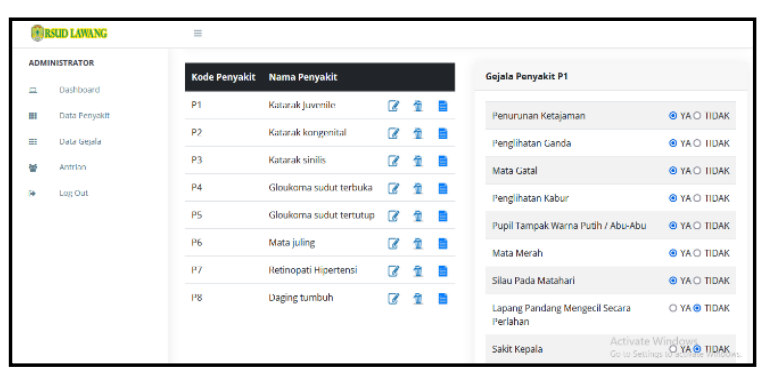

Gambar 9. Halaman Daftar Gejala yang

Berhubungan Dengan Penyakit

\subsection{Halaman Data Gejala}

Pada halaman ini menampilkan data gejala yang ada pada database, terdapat tombol tambah gejala, edit gejala, hapus gejala dan daftar penyakit yang berhubungan dengan gejala tersebut.

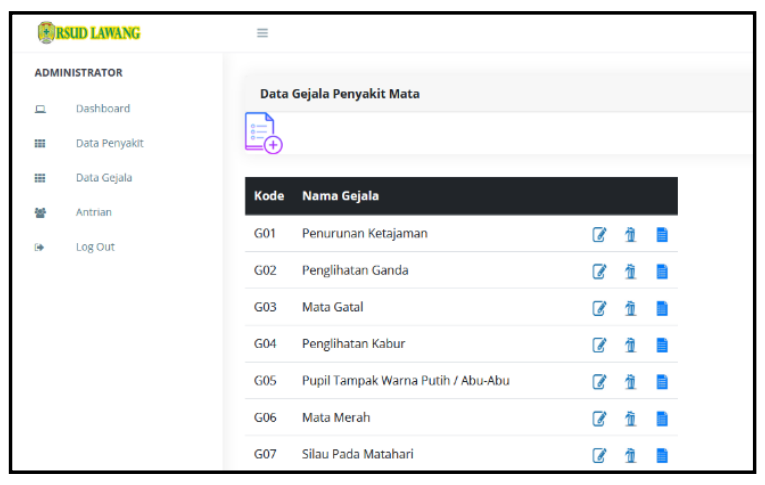

Gambar 10. Halaman Data Gejala

\subsection{Halaman Daftar Gejala yang Berhubungan Dengan Penyakit}

Pada halaman ini admin dapat melihat daftar penyakit yang berhubungan dengan gejala tersebut.

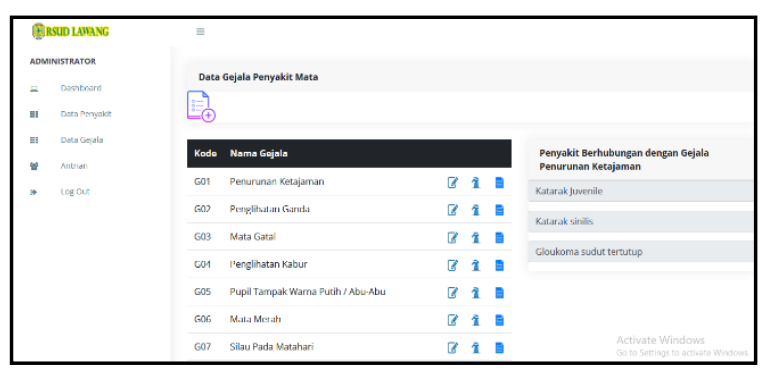

Gambar 11. Halaman Daftar Gejala yang

Berhubungan Dengan Penyakit

\subsection{Halaman Daftar Antrian}

Pada halaman ini admin memiliki hak ases untuk melihat daftar antrian pasien dan memiliki hak ases untuk melakukan perubahan maksimal antrian pasien dalam 1 hari.

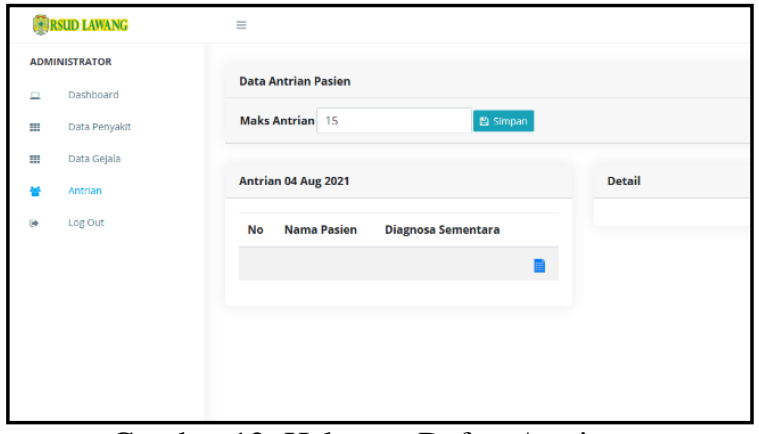

Gambar 12. Halaman Daftar Antrian

\subsection{Halaman Pendaftaran Pasien}

Pada halaman ini ada 2 pilihan yaitu "sing in" untuk pasien yang sudah memiliki akun yang terdaftar pada sistem dan "dafatar" untuk pasien yang belum memiliki akun. Pada piliha daftar, pasien wajib mengisi alamat email, nomor identitas berupa nomor KTP/SIM, nama lengkap sesuai identitas, password, jenis kelamin, alamat domisili dan nomor telepon.

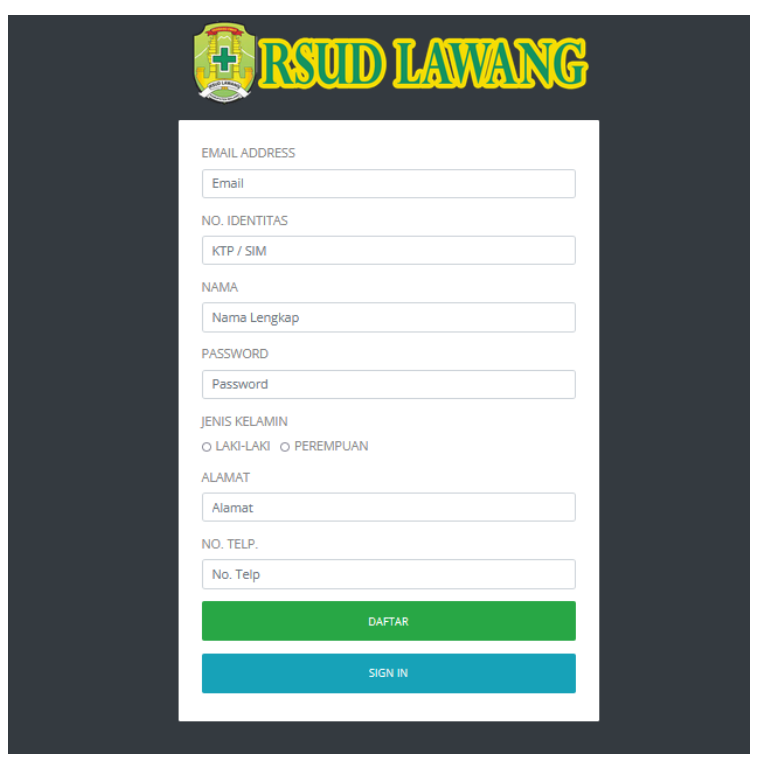

Gambar 13. Halaman Pendaftaran Pasien

\subsection{Halaman Dashboard Pasien}

Setelah berhasil login pasien akan muncul halaman dashboard pasien, pasien dapat memulai konsultasi dengan klik tombol cek gejala.

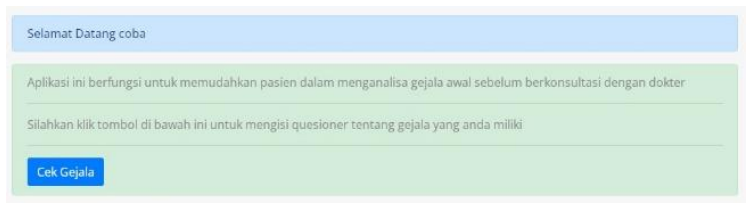

Gambar 14. Halaman Dashboard Pasien 


\subsection{Halaman Konsultasi Pasien}

Pada halaman konsultasi ini pasien dapat memilih sesuai gejala yang dialami.

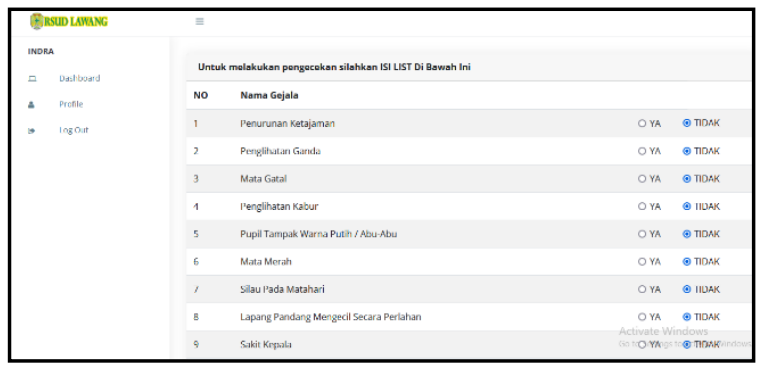

Gambar 15. Halaman Konsultasi Pasien

\subsection{Halaman Profil Pasien}

Pada menu profil, pasien dapat melihat dan melakukan perubahan data alamat email, nomor identitas, nama, jenis kelamin, alamat domisili dan nomor telepon.

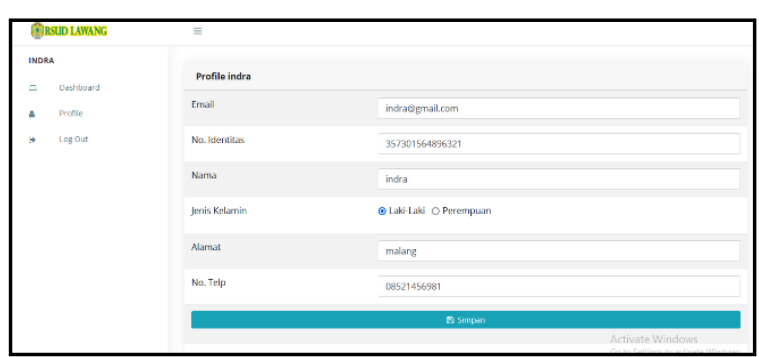

Gambar 16. Halaman Profil Pasien

\subsection{Halaman Hasil Konsultasi}

Setelah memilih gejala sesuai yang dialami, pasien dapat melihat hasil dari konsultasi berupa kesimpulan diagnosa. Pada halaman ini pasien juga dapat melakukan cek gejala ulang dengan klik tombol "cek lagi". Selain itu, jika pasien menginginkan konsultasi langsung dengan dokter spesialis mata, maka pasien dapat klik tombol "daftar poli mata".

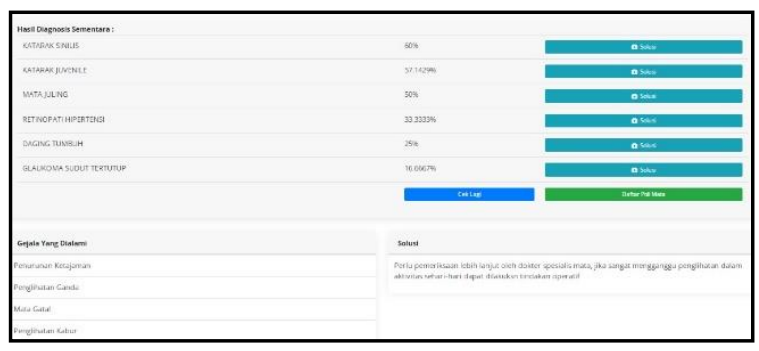

Gambar 17. Halaman Hasil Konsultasi

\subsection{Halaman Antrian}

Pada halaman ini pasien dapat memilih hari untuk berkonsultasi dengan dokter spesialis mata dan mendapatkan nomor antrian.

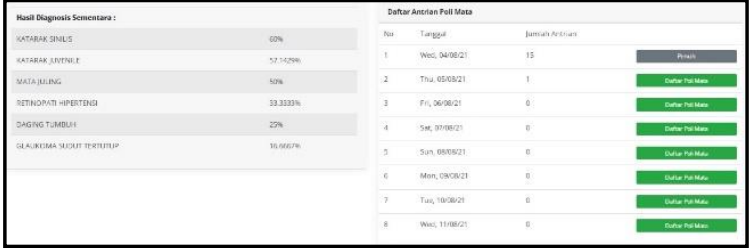

Gambar 18. Halaman Antrian Pasien

\section{KESIMPULAN DAN SARAN}

5.1. Kesimpulan

1. Dengan menggunakan metode forward chaining, Sistem pakar penyakit mata ini berhasil diwujudkan

2. Dari hasil pengujian dapat diketahui bahwa sistem ini berfungsi dengan baik, pada saat memberikan konsultasi penyakit mata, gejala serta solusi, pengolahan data berjalan dengan baik berupa data penyakit dan gejala pasien

3. Hasil analisa dan diagnosa penyakit sesuai dengan gejala-gejala yang diberikan oleh pasien.

4. Hasil output sudah sesuai dengan kebutuhan pasien dan dapat menjadi solusi konsultasi secara online

\subsection{Saran}

1. Dapat dikembangkan dengan berbasis android sehingga lebih mudah diakses.

2. Diharapkan sistem ini dapat menampilkan laporan jumlah pasien yang telah melakukan konsultasi tiap harinya

\section{DAFTAR PUSTAKA}

[1] E. Ongko, 2013. "Perancangan Sistem Pakar Diagnosa Penyakit pada Mata", JTM, vol. 2, no. 2.

[2] Ganong, W. F. 2003. Buku Ajar Kedokteran, Edisi Duapuluh. Jakarta: Buku Kedokteran EGC.

[3] Hadi, Mohamad., Misdram, M., dan Aini, R. F. 2016. "Perancangan Sistem Pakar Diagnosis Penyakit Ayam Dengan Metode Forward Chaining", Jurnal Informatika Merdeka Pasuruan, vol. 2, no. 1, pp. 111-19.

[4] Hamdani. 2010. "Sistem Pakar Untuk Diagnosa Penyakit Mata Pada Manusia", Jurnal Informatika Mulawarman, vol. 5, no. 2, pp. 13-21

[5] "Keputusan menteri kesehatan Republik Indonesia No.129/Menkes/SK/IV/2008tentang Standar Pelayanan Minimal di Rumah Sakit". 2008.

[6] Kusumadwi, Sri, Artificial Intelligence (Teknik dan Aplikasinya), 2003, Penerbit Graha Ilmu, Yogyakarta.

[7] Ongko, Erianto. 2013. "Perancangan Sistem Pakar Diagnosa Penyakit Pada Mata", Jurnal TIME, vol. 2, no. 2, pp. 10-17.

[8] Rahmatullah, Syaifur., Purnia, D. F., Suryanto, Ade. 2018. "Sistem Pakar Untuk Mendiagnosa 
Penyakit Mata Dengan Metode Forward Chaining", Sentra Penelitian Engineering dan Edukasi, vol. 10, no. 2, pp. 56-62.

[9] Reisa, Reppy., Jusak., dan Sudarmaningtyas, Pantjawati. 2013. "Sistem Pakar Untuk Diagnosis Penyakit Mata", JSIKA, vol. 2, no. 2, pp. 30-39.

[10] Sutojo, T., Edy Mulyanto, Vincent Suhartono, Kecerdasan Buatan, 2001, Penerbit Andi, Yogyakarta.

[11] Turban, E., Aronson, J.E., Ting, P.L., 2005. "Decision Support System and Intelligent Sysytems" Prentice-Hall of India. New Delhi.
[12] Widianingsih, Ratri., Kridalaksana, A. H., dan Hakim, A. R. 2010. "Aplikasi Tes Buta Warna Dengan Metode Ishihara Berbasis Komputer”, Jurnal Informatika Mulawarman, vol. 5, no. 1, pp. 6-41.

[13] "World Health Organization Blindness and vision impairment". 2014.

[14] Yanto, B. F., Werdiningsih, Indah, dan Purwanti, Endah. 2017. "Aplikasi Sistem Pakar Diagnosa Penyakit Pada Anak Bawah Lima Tahun Menggunakan Metode Forward Chaining”. JISEBI, pp. 61-67 